\title{
Characterization of Microbial Community Changes in Process Affected by Physicochemical Parameters During Liquid Fertilization of Swine Waste
}

\author{
Mi-Na Shin ${ }^{\dagger}$, Jin-Won Kim ${ }^{\dagger}$, Jaehong Shim, Heung-Hoe Koo ${ }^{1}$, Jai-Young Lee', \\ Min Cho, and Byung-Taek Oh* \\ Division of Biotechnology, Advanced Institute of Environment and Bioscience, College of Environmental and Bioresource \\ Sciences, Chonbuk National University, Iksan, Jeonbuk 570-752, South Korea \\ ${ }^{1}$ Semyong Engineering, Incheon 405-817, South Korea \\ ${ }^{2}$ Department of Environmental Engineering, The University of Seoul, Seoul 130-743, South Korea
}

(Received: May 6 2013, Accepted: May 22 2013)

\begin{abstract}
Livestock wastes are considered as major environmental pollutants because they contain high concentration of organic materials. In 2001, The Environmental Department reported that stock farmers were increasing as $5.1 \%$ year, which resulted in a gradual increase in livestock wastes generation. The direct disposal of livestock wastes create several environmental problems. Thus, several countries banned the disposal of livestock wastes in environment including aquatic systems. Recently, aeration-based liquid fertilization was considered as potential way for the disposal of livestock wastes. In this study, next generation sequencing (NGS) analysis was used to understand the microbial community changes during liquid fertilization of livestock wastes. Microbial community was compared with liquid fertilizer physicochemical analysis such as $\mathbf{B O D}_{5}, \mathbf{C O D}_{\mathrm{Mn}}$, pH, N (Nitrogen), P (Phosphorus), K (Potassium) etc. The physicochemical parameters and bacterial community results pave the way for producing effective livestock-based fertilizer. By comparing the physical characteristics of the manure with microbial community changes, it is possible to optimize the conditions for producing effective fertilizer.
\end{abstract}

Key words: Livestock wastes, Liquid fertilization, NGS (next generation sequencing), $\mathrm{BOD}_{5}, \mathrm{COD}_{\mathrm{Mn}}$

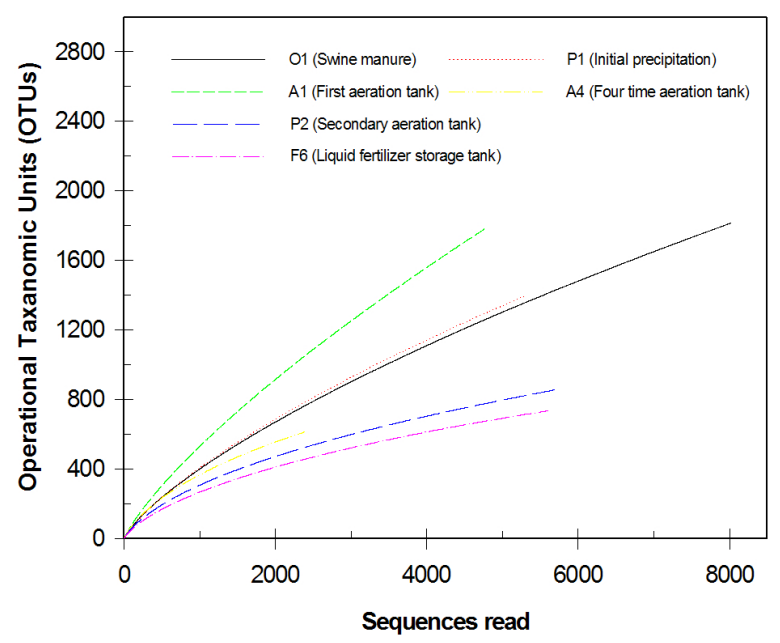

Influence of fertilization process on microorganisms diversity and physicochemical components such as $\mathrm{BOD}_{5}, \mathrm{COD}_{\mathrm{Mn}}$ and T-N. The results showed a decrease in microorganisms diversity during liquid fertilization process.

\footnotetext{
*Corresponding author : Phone: +82638500838, Fax: +82638500834, Email: btoh@jbnu.ac.kr

${ }^{\dagger}$ Both authors contributed equally to this work and are considered as co-first authors

${ }^{\S}$ Acknowledgement: This subject is supported by Korea Ministry of Environment(MOE) as "Eco-innovation Program" (Project No. E211-40005-0047-1)
} 


\section{Introduction}

2011년도 환경부에서 발표한 “가축분뇨 발생량 및 처리현 황 (2011)”에 따르면 젖소, 소 (한우), 말, 돼지, 양, 사슴, 닭, 오리, 개 등 10 개 축종에 대하여 조사한 결과 11 년도의 경우 10 년도 대비 $5.1 \%$ 만큼 축산농가가 증가하였으며, 전 체 사육두수는 $0.6 \%$ 만큼 증가 된 것으로 보고되었다. 가축 사육두수 증가와 더불어서 가축분뇨발생 증가에 대한 우려 가 높아지고 있다. 2011년도 까지 매년 발생하는 상당수의 분뇨는 해양투기가 이루어 졌으나 런던협약 체결로 인하여 2012년도부터 국내에서 발생하는 가축분뇨의 해양투기가 금지됨에 따라 매년 발생되는 분뇨의 처리에 대한 방안 마 련이 시급해졌다 $(\mathrm{Kim}, 2007)$.

환경 중 가축분뇨 처리문제의 해결방안으로 최근 돈분의 액비화에 대한 연구가 활발하게 이루어지고 있다 (Jeong et al., 2012). Hess et al. (2004)에 따르면 가축 분의 퇴, 액비 화 과정에서 미생물에 의해 유기물이 분해되어 $\mathrm{BOD}, \mathrm{COD}$, $\mathrm{T}-\mathrm{N}$ 등 유기물 오염지표 농도의 감소 효과를 나타내며, 이 때 발생한 고온의 열로 인하여 병원성 미생물이 사멸됨이 알려진바 있다. 이러한 점에서 고농도 유기성 폐기물인 돈 분의 처리과정은 생물학적 폐수처리 공정에서 미생물 군집 의 역할과 유사하다. 실제로 액비화 과정 및 하수처리과정 에서 다양한 미생물들은 분해되기 쉬운 유기물의 분해를 촉 진시켜 폐수 내 양분을 안정한 상태로 만들어준다.

현재 국내에서는 폐기가 힘든 가축분뇨 중 $85 \%$ 를 자원화 (퇴비 및 액비) 과정을 거쳐 이용되고 있다 (Kwon et al., 2010). Dong and Reddy (2010)에 따르면 실제 가축분뇨는 농업 작물의 생산을 위한 중요하고 가치 있는 비료임이 확 인된 바 있다. 특히 가축분뇨의 경우 식물의 성장에 필요한 다양한 유기 및 무기원소를 포함하고 있어 식물의 생산량을 증대 시킬 수 있는 좋은 자원이 될 수 있다고 알려져 있다.

그러나 특별한 처리 없이 비료로서 무분별한 가축분뇨의 사용은 분뇨내 병원성 미생물, 중금속, 잔류오염물질에 의 한 2차적인 오염을 발생시킬 수 있다 (Hölzel et al., 2010; Jung et al., 2011). 이와 더불어서 오염지표를 나타내는 $\mathrm{BOD}, \mathrm{COD}$ 수치가 하수 방류 기준치를 초과하므로 환경 중 에 노출 시 하천수 오염, 악취, 적조발생 등의 위험성을 안 고 있다.

돈분의 액비화 방법에는 크게 혐기성과 호기성 액비화로 구분된다. 혐기성 액비화의 경우에는 상대적인 슬러지 생성 이 호기성 액비화에 비해 적으며, 메탄가스를 발생시킴으로 서 에너지로 이용 가능하다는 장점이 있지만, 호기성 액비 화에 비해 액비생성을 위한 기간이 3달 이상으로 상대적으 로 길다. 반면 호기성 액비화의 경우에는 부숙된 액비를 생 산하는데 약 30 40일 정도로 완숙된 액비 생산을 위해 상 대적으로 짧은 기간을 필요로 한다.
퇴·액비화 과정은 일반적으로 세균, 진균, 방선균의 분해 작용을 통해 이루어진다고 알려져 있다. 특히 액비화 초기 에는 미생물에 의한 유기물 분해 작용이 활발하여 전체적인 액비 성상에 큰 영향을 미친다. 이렇듯 액비화과정의 주요 인자로 미생물의 대사 작용이 관여하며, 대사 작용의 메커 니즘은 우점 하는 미생물의 종류에 크게 좌우된다. 따라서 본 연구 목적은 효율적인 돈분 액비화 공정을 설계하는데 필요한 자료를 활용하기 위함이다.

본 연구에서는 경남 $\mathrm{A}$ 지역에서 운영되고 있는 가축분뇨 자원화 시설의 각 공정에서 시료를 채취하여 액비화 과정 중 미생물의 역할을 확인하였다. 액비화 시료의 미생물 군 집분석을 위해 일반적으로 미생물 배지에 도말 하여 배양 가능한 미생물 및 DGGE (Denature Gradient Gel Electrophoresis), TGGE (Temperature Gradient Gel Electrophoresis), T-RFLP (Terminal Restriction Fragment Length Polymorphism), AFLP (Amplified Fragment Length Polymorphism) 등과 같은 군집분석을 위한 다양한 방법이 제시되었다 (Park et al., 2011). 그러나 배양 가능한 미생물 분석의 경 우 자연계에 존재하는 미생물의 $90 \%$ 이상이 일반적인 실험 실 환경에서 배양이 되지 않으므로 제한 점을 가진다. 또한, Adams et al. (2009)에 따르면 DGGE, TGGE, RFLP 등의 배양에 의존하지 않는 방법이 개발되기는 했으나 결과의 데 이터베이스화 및 종 (specie)의 정보를 얻는 것이 불가능하 고 광범위한 범위의 metagenomics 분석이 힘들다는 점을 감안하여, 본 연구에서는 원분뇨 내 미생물 군집의 분석 신 뢰도를 높이기 위한 방법으로 차세대염기서열분석 (Next Generation Sequencing) 기술인 pyrosequncing을 활용하 여 분석을 실시하였다.

본 연구에서는 $16 \mathrm{~S}$ rRNA 유전자 기반의 pyrosequencing 분석결과를 통해 얻은 우점하는 미생물의 종류와 액비화 과 정의 물리화학적 성상 분석 결과 사이의 비교를 실시하였 다. 미생물에 의한 액비화 작용과 액비 성상 변화 사이의 비 교를 통하여 최종적으로 각 처리공정에서 다양한 미생물 군 집의 생태학적인 특성을 확인하고 추후 더 효율적인 액비화 과정을 위한 기초 정보를 제공하고자 한다.

\section{Materials and Methods}

액비화 시설 및 시료채취 본 연구에서 사용된 돈분뇨 및 각 공정의 액비 시료는 다단계, 하향 포기 방식으로 운영 되는 경남 $\mathrm{A}$ 지역의 액비 자원화 시설 ( 1 일 처리용량 약 12 톤 규모)에서 이루어졌다. 시료채취 시기는 10 월 중순경이었으 며, 돈사의 원분뇨 $(\mathrm{O} 1), 1$ 차 침전조 $(\mathrm{P} 1)$, 폭기조 $(1,4$ 차 $\mathrm{A} 1 \sim \mathrm{A} 4), 2$ 차 침전조 (P2), 최종 액비 (6차 폭기조 F6)로 분 류하여 $2 \mathrm{~L}$ 체수병에 시료를 채취하였으며, 액비화 시설의 공정도는 Fig. 1 에 나타내었다. 채취된 시료는 $-4{ }^{\circ} \mathrm{C}$ 냉장상 


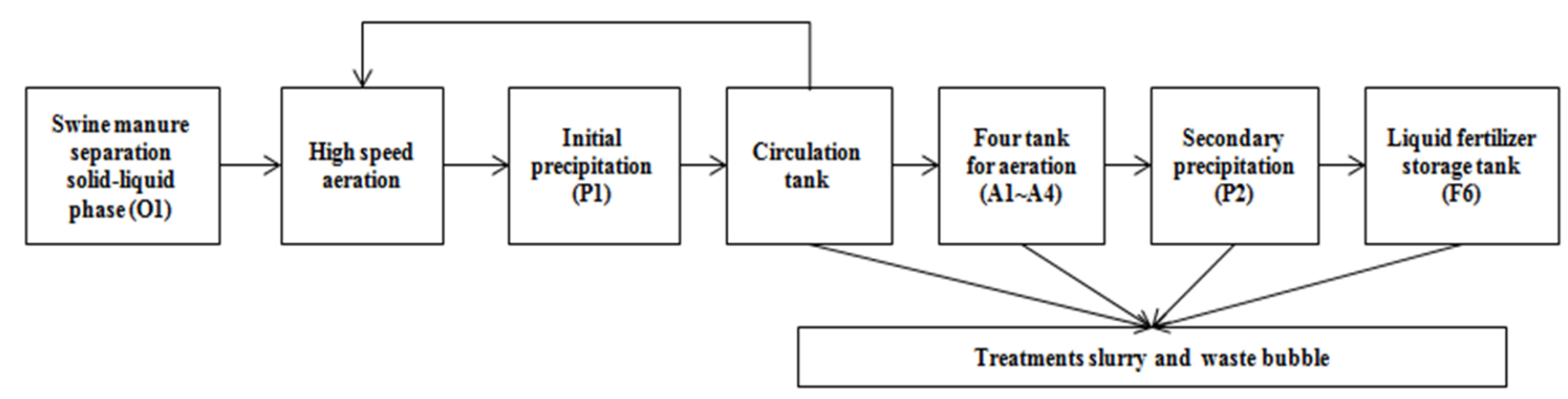

Fig. 1. Schematic diagram of the swine fertilization process by aerations and precipitations.

태로 운반하였으며, $-4^{\circ} \mathrm{C}$ 냉장 상에서 보관하였다.

본 액비 자원화 시설의 액비화 과정은 다음과 같다. 진동 형 고액분리기를 통해 고액분리를 거친 돈분 시료는 24 시간 동안 5 톤 처리용량의 이동식 고속 다단계 폭기조를 거치며, 이후 1 차 침전을 통해 생성된 슬러지를 제거한다. 침전을 거친 돈분시료의 상등액은 폭기조로 이동하며, 펌프를 통해 시료를 끌어올려 폭기조 상부로 떨어뜨리는 방식으로 1 번 폭기조에서 4번 폭기조까지 1일 6시간 동안 폭기시켜준다. 4 차례의 폭기를 거친 시료는 2 차 침전조에서 추가적인 침전 과정을 거친 후 상등액은 최종 액비 저장조에서 일정기간 동안 부숙 과정을 거쳐 액비로 사용된다.

액비 성상분석 및 중금속 함량 분석 각 공정별로 채 취한 시료 $5 \mathrm{~mL}$ 을 질산 $10 \mathrm{~mL}$ 에 하루 방치한 후 전열판 위 에서 흰 침전물이 생길 때까지 서서히 가열하고 방냉하였 다. 준비한 Ternary solution $\left(\mathrm{HNO}_{3}, \mathrm{H}_{2} \mathrm{SO}_{4}, \mathrm{HClO}_{4}\right.$ 각각 10 $: 1: 4$ 비율로 혼합)을 $10 \sim 50 \mathrm{~mL}$ 넣고 시료가 투명하게 될 때까지 가열시켰다. 분해된 시료를 No. 6 여과지로 여과 후 $100 \mathrm{~mL}$ 매스플라스크에 정량하였다. 희석된 시료는 ICP-OES (Leemans Labs, Inc., Hudson, NH, USA)를 이용하여 $\mathrm{Hg}, \mathrm{Cr}$ 을 제외한 $\mathrm{As}, \mathrm{Cu}, \mathrm{Zn}, \mathrm{Ni}, \mathrm{Pb}, \mathrm{Cd}$ 가지 항목에 대해 분석을 실시하였다 (Gutierrez et al., 2010).

수질오염공정시험법에 따라 $\mathrm{COD}_{\mathrm{Mn}}$ 는 과망간산칼륨법, $\mathrm{BOD}_{5}$ 는 $\mathrm{DO}$ meter를 이용하여 5 일간 $20^{\circ} \mathrm{C}$ 에서 배양하여 분 석을 실시하였고, $\mathrm{T}-\mathrm{N}$ 은 자외선 흡광광도법을 이용하여 분 석을 실시하였다.

미생물 분리 각 공정별 배양 가능한 미생물 분석을 위 하여 채취한 시료를 멸균된 $0.85 \%$ saline solution에 $10^{-6}$ serial dilution하여 LB agar배지에 평판 도말을 실시하였 다. 도말된 배지는 $30^{\circ} \mathrm{C}$ 에서 2 일간 배양하였으며, 도말된 배지에서 생성된 미생물 콜로니의 형태적 특성을 토대로 순 수 분리하였다. 분리된 미생물은 개별적으로 $\mathrm{LB}$ broth medium에 계대배양 후 $10 \%$ glycerol stock을 만들어 $-80^{\circ} \mathrm{C}$ 냉동고에 보관하여 실험에 사용하였다.
DNA 추출 및 미생물 $16 \mathrm{~S}$ RNA의 pyrosequencing 본 액비화 공정으로부터 채취한 시료 내에서 DNA의 추출방 법은 Kim et al. (2010)에 따라 진행하였다. 추출된 시료의 $16 \mathrm{~S} \mathrm{rDNA}$ 부분을 $\mathrm{PCR}$ 을 이용하여 증폭하고자 universal primer인 27F (5'-AGAGTTTGATCATGGCTCAG-3'), 1492R (5'-GGTTACCTTGTTACGACTT-3')을 이용하였다 (Reysenbach A.L. et al., 1992). PCR산물은 QIAquick Gel Extraction kit (Qiagen, CA, USA)를 사용하여 정제하였다. Nam et al. (2012)에 따라 증폭된 미생물의 $16 \mathrm{~S}$ rRNA 부분에 V1, V2의 hyper variable regions (HVRs) barcoded pyrocequencing 방법을 이용하였으며, Roche 454 pyrosequencing Genome Sequencer FLX Titanium system 염기서열 분석기를 사용 하여 pyrosequencing을 진행하였다. Pyrosequencing 분석 을 위하여 본 액비화 공정에서 채취된 시료는 국내 sequencing service 회사에서 수행되었다 (Chunlab Inc., Republic of Korea).

통계학적 분석 본 연구에서 실시한 모든 통계학적 분 석은 모두 SAS 9.1 (USA) program을 이용하여 진행되었다. 데이터 분석은 일원배치 분산분석 (Oneway-ANOVA)으로 진행되었으며, 개별적으로 $\mathrm{P} \leq 0.05$ 유의성 수준에서 Duncan's multi range test (DMRT)를 실시하였다.

\section{Results and Discussion}

돈분내 미생물 군집 및 고속폭기 이후 미생물 군집 의 분포 양상 돈분의 액비화 과정에 미치는 미생물 군집 의 영향을 확인하기 위해 액비자원화 시설로부터 채취한 시 료를 $16 \mathrm{~S}$ rRNA를 기반으로 한 pyrosequencing 방법을 이용 하여 돈분의 액비화 공정 내 미생물군집 분석을 실시하였 다. 2 단계 진동스크린을 이용하여 고액분리를 거친 원분뇨 내 미생물 군집을 문 (Phylum) 수준에서 비교하였을 때, Firmicutes (37.73\%), Proteobacteria (28.74\%), Bacteroidetes (21.16\%), Actinobacteria (3.14\%) 비율이었다 (Table 1).

Kim et al. (2010)과 Unno et al. (2010)에 따르면 인간의 
Table 1. 16S rRNA pyrosequencing read analysis of each swine waste fertilization process. O1 (Swine manure), P1 (Initial precipitation), A1 (First aeration tank), A4 (Four time aeration tank), P2 (Secondary aeration tank), F6 (Liquid fertilizer storage tank).

\begin{tabular}{lccccccc}
\hline \hline Phylum & AVE $^{\dagger} .(\%)$ & O1 $(\%)$ & P1 (\%) & A1 (\%) & A4 (\%) & P2 (\%) & F6 (\%) \\
\hline Firmicutes & 41.96 & 37.73 & 46.81 & 46.29 & 26.78 & 40.5 & 53.65 \\
Bacteroidetes & 31.58 & 21.16 & 36.04 & 25.78 & 31.5 & 43.87 & 31.12 \\
Proteobacteria & 12.33 & 28.74 & 2.45 & 11.69 & 17.17 & 8.64 & 5.28 \\
Actinobacteria & 3.75 & 3.14 & 1.77 & 2.25 & 11.28 & 2.0 & 2.05 \\
Tenericutes & 1.97 & 0.45 & 3.48 & 2.83 & 2.26 & 0.96 & 1.85 \\
Spirochaetes & 1.67 & 1.1 & 3.97 & 3.36 & 0.33 & 0.05 & 1.23 \\
Synergisetes & 1.3 & 2.49 & 1.81 & 1.29 & 0.75 & 0.23 & 1.25 \\
Deinococcus-Thermus & 1.48 & $\mathrm{ND}$ & $\mathrm{ND}$ & 3.56 & 3.88 & 0.83 & 0.59 \\
\hline
\end{tabular}

${ }^{\dagger} \mathrm{AVE}$ : Average, ${ }^{\dagger} \mathrm{ND}$ : Not detected.

분뇨내 박테리아와 가축분뇨에서 주로 발견되는 박테리아 는 Bacteroidetes, Firmicutes 이며, 본 실험에 사용된 돈분 시료 내 미생물 분포양상도 이와 유사함을 확인하였다. 그 러나 Kim et al. (2010)에 따르면 이러한 결과는 담수, 하수 슬러지 등에서 발견되는 주요 박테리아 문의 50 70\%가 Proteobacteria인 점을 고려하였을 때, 상이한 분석결과임 을 확인 하였다.

1 일 5 톤의 분뇨 처리용량을 가진 고속 폭기조에서 약 40 60 $\mathrm{Km} \mathrm{h}^{-1}$ 로 24시간 동안 연속적인 폭기를 거친 후 침 전시킨 1차 침전조의 시료에서 문 수준의 미생물을 분석한 결과 Firmicutes (46.81\%), Bacteroidetes (36.04\%), Proteobacteria (2.45\%), Actinobacteria (1.77\%) 비율이었다. 이러한 결과 를 통하여 고액분리를 거친 돈분을 약 8일간 고속으로 폭기 해주었을 때, Firmicutes 문과 Bacteroidetes 문이 크게 증 가함을 확인할 수 있었다. 반면, 초기 돈분에서 상대적으로 높은 비율로 우점하였던 Proteobacteria 문은 크게 감소하 는 경향을 보였는데, 이러한 Proteobacteria 문의 감소는 다 음과 같은 문의 대부분을 구성하고 있던 Pseudomonas (21.53\%) 속의 급격한 감소로 인한 결과임을 확인하였다.

Proteobacteria 문의 감소경향과 반대로 Firmicutes문의 경우 상대적인 비율이 약 $9 \%$ 증가됨을 확인할 수 있었다. Sung et al. (2011)에 따르면 Firmicutes 문은 내생포자 (endospore) 형성집단이 주로 속하는 문으로 Clostridium 속, Bacilli 속 등의 미생물 속을 포함하고 있어 고속폭기 동 안 불리한 환경에서 내생포자 형태로 존재할 수 있음이 알 려져 있다. 실제 시료 내에서 Firmicutes 목에 속하는 Cloststridia 속을 분석한 결과 1차 침전조 시료에서 Cloststridia 속이 전체 속의 $22.78 \%$ 차지함으로써 초기 고속으로 폭기 하는 과정에서 우점하고 있음을 확인하였다. 또한, 이러한 내생포자를 형성하는 미생물은 Sung et al. (2011)에 따르면 난분해성 물질의 분해와 악취성분 제거능이 우수하다고 알 려져 있다.
이러한 분석 결과는 고속폭기 방식의 이동식 다단계 노 즐 폭기조 운용시 미생물 대사 작용에 의해 발생한 열이 Cloststridia sp. 와 같은 내생포자형성 균이 우점 할 수 있는 환경을 조성하였음을 보여준다. 액비화 초기 단계에서 우점 하게 될 확률이 높은 Firmicutes 문의 Clostridium 속, Bacilli 속 등의 미생물을 적용할 경우 단기간 내에 우수한 유기물 분해 효과를 얻을 수 있을 것으로 사료된다.

돈분의 액비화를 진행함에 있어서 병원성 미생물 제어 측면의 장점을 확인하기 위하여 병원성 미생물에 대한 분석 을 실시하였다. 분석결과 고액분리를 거친 원분뇨 시료내에 서 분변오염의 지표세균인 Escherichia coli가 존재함을 확 인하였다. 이밖에도 Jung et al. (2011)에 따라 식중독 사고 를 일으킬 수 있는 잠재적인 위험성을 가진 6 개 종의 미생 물 분석한 결과 Salmonella sp., Staphylococcus aureus, Listeria monocytogenes, Bacillus cereus, Enterobacter sakazaki, Vibrio sp. 등은 동정되지 않았다.

\section{고속폭기 이후 미생물 군집의 분포 변화에 따른 액} 비 성상변화 비교 액비화 초기 단계에서 고속폭기는 미 생물 군집 변화와 시료의 성상에 크게 영향을 미치는 것을 확인하였다. 고농도 유기성 폐기물인 돈분뇨 특성상 고액분 리를 거친 원분뇨에서 높은 $\mathrm{BOD}_{5}, \mathrm{COD}_{\mathrm{Mn}}$ 농도를 확인 할 수 있었으며, 돈분의 고속폭기 과정 동안 $\mathrm{BOD}_{5}, \mathrm{COD}_{\mathrm{Mn}}$ 의 농도가 크게 감소함을 확인하였다 (Fig. 2). 초기 고속폭기 과정 동안 생물학적 산소요구량을 나타내는 $\mathrm{BOD}_{5}$ 는 약 $87.8 \%$, 화학적 산소요구량인 $\mathrm{COD}_{\mathrm{Mn}}$ 는 약 $94.1 \%$ 의 감소를 보였다.

$\mathrm{BOD}_{5}, \mathrm{COD}_{\mathrm{Mn}}$ 등 유기성 오염물의 지표가 감소하는 경향 과 더불어서 액비내 총 질소 $(\mathrm{T}-\mathrm{N})$ 는 약 $68.18 \%$ 감소하였 다 (Fig. 3). 또한, 1차 침전조에서 암모니아태 질소 $\left(\mathrm{NH}_{3}-\mathrm{N}\right)$ 를 분석한 결과 총질소의 대부분이 $\mathrm{NH}_{3}$ 형태 질소로 구성되 어있음을 확인하였다. 실제 액비내 질소는 대기 중으로 $\mathrm{NH}_{3}$ 


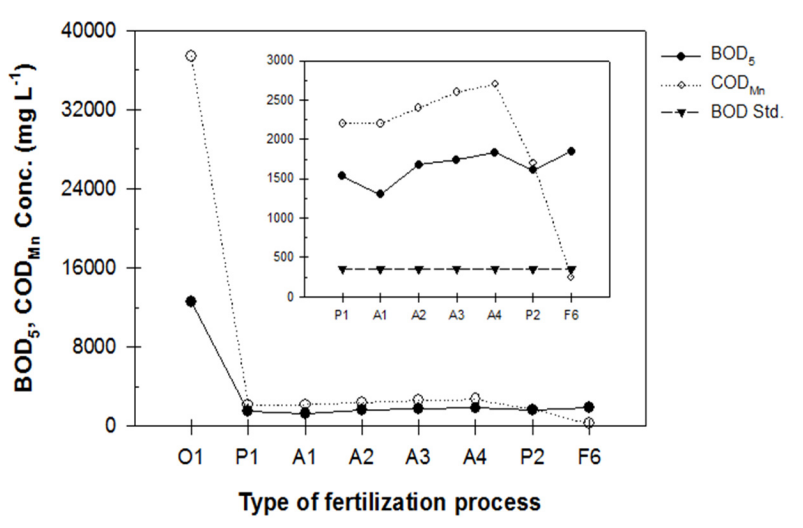

Fig. 2. Influence of fertilization process on $\mathrm{BOD}_{5}, \mathrm{COD}_{\mathrm{Mn}}$ concentration.

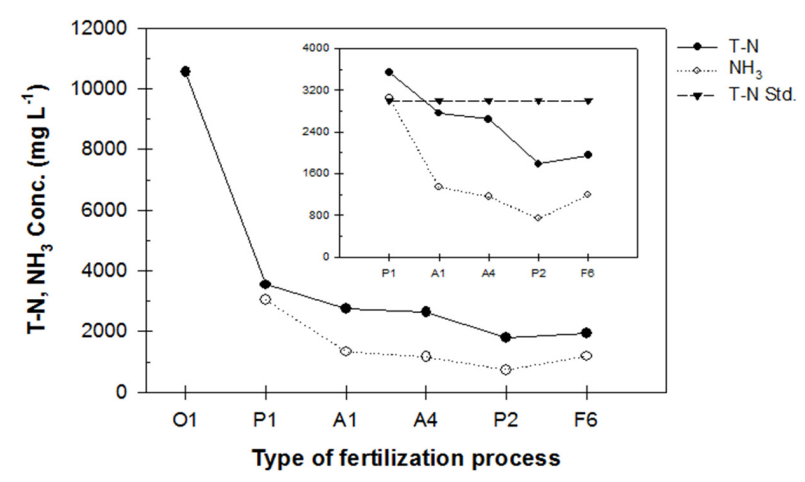

Fig. 3. Influence of fertilization process on $\mathrm{T}-\mathrm{N}, \mathrm{NH}_{3}$ concentration.

형태로 휘산되어 액비 내 질소함량이 감소된다고 알려진바 있다.

액비화 과정에서 질소의 이동은 $\mathrm{NH}_{3}$ 상태에서 Nitrosomonas sp. 에 의해 $\mathrm{NH}_{4}{ }^{+}$형태로 전환과 Pseudomonas sp., Methylobacterium sp., Bacillus sp. 등의 미생물에 의해 $\mathrm{NO}_{3}{ }^{-}$의 형 태로 변화가 이루어짐이 알려져 있다 (Wagner et al., 2002). 이밖에도 액비화 초기 환경조건에 의한 유기산 생성 으로 $\mathrm{pH}$ 감소가 이루어진 후 유기산 분해 및 질소화합물의 산화로부터 $\mathrm{NH}_{3}$ 가 생성될 수 있으며, 이로 인한 $\mathrm{pH}$ 증가가 보고되었다 (Ryoo, 2010). 본 연구결과에서도 액비화 과정 에서 다음과 같은 반응단계가 진행됨을 확인할 수 있었다.

식물이 대부분 이용하는 질소의 형태는 $\mathrm{NO}_{3}{ }^{-}$의 질산염 형태로 알려져 있다 (Gangwar and Singh, 2011; Gajewska and Sklodowska, 2009). 그러나 Jin et al. (2003)과 Park et al. (1998)에 따르면 $\mathrm{NH}_{4}{ }^{+}$형태도 식물에 의해 흡수 될 수 있는데 이러한 형태의 질소는 몇몇 식물에 질산태 질소의 흡수, 세포증식률 저하 등의 증상을 나타낼 수 있음이 알려 진바 있으며, 질소의 이용 형태는 식물의 종류마다 다름을 고려하였을 때, 액비 공정 및 단계에 따른 질소 형태분석과 이에 대한 추가적인 연구가 필요하다고 사료된다.

\section{고속폭기 이후 연속적인 폭기에 따른 미생물 군집} 의 분포 양상 확인 고액분리를 거친 돈분 시료는 24 시 간 동안 고속폭기 및 1 회의 침전을 거친 후 폭기조로 이동 되었다. 이동된 시료는 1 차 폭기조에서 4 차 폭기조까지 12 톤 처리용량을 가진 각각의 처리조에서 1일 6시간 40 50 $\mathrm{Km} \mathrm{h}^{-1}$ 의 포기량으로 4 차례 돈분 시료를 펌프로 끌어올려 떨어뜨리는 방식으로 폭기 시켜주었다.

이러한 과정을 거친 1 차 폭기조, 4 차 폭기조 시료의 미생 물을 문 수준에서 분석한 결과 1차 폭기조의 경우 Firmicutes (46.29\%), Proteobacteria (11.69\%), Bacteroidetes (25.78\%), Actinobacteria (2.25\%)로 분석되었으며, 4 차 폭기조의 경 우 Firmicutes (26.78\%), Proteobacteria (17.17\%), Bacteroidetes (31.5\%), Actinobacteria (11.28\%) 순으로 분석되었다.

4차례의 추가적인 폭기를 거치는 동안 Proteobacteria, Bacteroidetes, Actinobacteria 문의 비율이 크게 증가함을 확인하였다. 특히 침전조 1 에서 $2.45 \%$ 까지 감소되었던 Proteobacteria 문은 17.17\%까지, Actinobacteria 문은 폭기조 4 번에서 $11.28 \%$ 까지 각각 증가하였다. 다음과 같은 폭기과 정 동안 특히 Actinobacteria 문이 크게 증가한 것을 확인 할 수 있었다. 이것은 액비화 초기 고속분해와 1 4차까지 폭기를 거치며 분해되기 쉬운 양분의 감소로 인한 결과로 해 석된다.

1 차 폭기 시료에서는 1 차 침전조 시료에서 발견되지 않은 Dinococcus-Thermus 문의 미생물이 $3.56 \%$ 비율로 검출되 었다. 갑작스런 문 수준의 미생물 개체수 증가 요인은 액비 화 공정 원시료의 차이 혹은 외부로부터의 유입 등의 원인 으로부터 기여됐을 것으로 추측된다. 이러한 문에 속하는 미생물은 극한의 환경조건에서 서식하며, 방사성 물질과 같 은 독성물질에 큰 내성을 보유하고 있다고 알려져 있다.

1차에서 4차까지의 폭기과정을 거치면서 Proteobacteria 문에 속하는 Betaproteobacteria 강에서 원분뇨와 침전조 1 에서 검출되지 않은 Nitrosomonadales 목의 미생물이 검출 되었다. Nitrosomonadales 목의 미생물은 하수처리계, 담 수, 해수 등에 서식하며 암모니아를 산화하여 아질산염으로 만들고 이렇게 만들어진 질산염의 형태는 식물에 의해 쉽게 이용될 수 있다고 알려져 있다 (Kim and Kim, 2006). 또한, 폭기조 4번 시료의 NGS 데이터베이스에서는 Alphaproteobacteria 강에 속하는 Nitrobacter vulgais 미생물이 검 출되었다. 이러한 미생물은 아질산염을 질산염형태로 산화 시킨다고 알려져 있으며, 다음과 같은 미생물들에 의한 암 모니아, 암모늄 형태 질소의 산화는 침전조 1 에서 급격한 $\mathrm{pH}$ 감소와 연관된다 (Fig. 4).

연속적인 폭기 과정에서 NGS 데이터베이스를 바탕으로 병원성 미생물을 분석한 결과 1차 폭기조에서 병원성 미생 물인 Vibrio sp. 가 검출되었으나, 1 차폭기 이후 4차 폭기조 에서는 검출되지 않았다 (Table 2). 이외 NGS program data상 


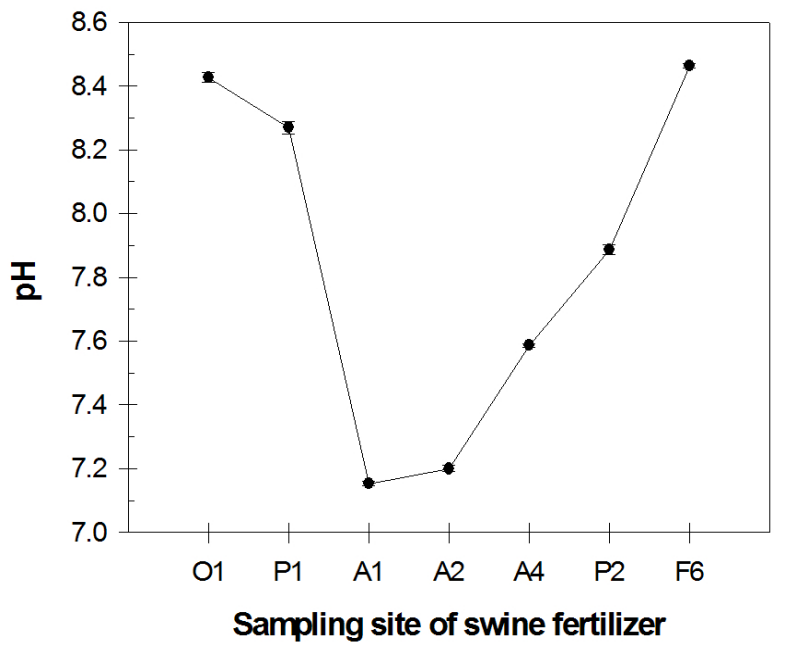

Fig. 4. Influence of fertilization process on $\mathrm{pH}$.

Table 2. Pathogenic bacteria analysis from each swine waste fertilization process.

\begin{tabular}{lcccccc}
\hline \hline & $\mathrm{O} 1$ & $\mathrm{P} 1$ & $\mathrm{~A} 1$ & $\mathrm{~A} 4$ & $\mathrm{P} 2$ & $\mathrm{~F} 6$ \\
\hline B. cereus & $+^{\dagger}$ & - & - & - & - & - \\
\hline E. coli & $-{ }^{\ddagger}$ & - & - & - & - & - \\
\hline E. sakazaki & - & - & - & - & - & - \\
\hline L. monocytogenes & - & - & - & - & - & - \\
\hline S. aureus & - & - & - & - & - & - \\
\hline Salmonella sp. & - & - & - & - & - & - \\
\hline Vibrio sp. & - & - & + & - & - & - \\
\hline+ : Detected, ${ }_{-}^{\ddagger}:$ Not detected
\end{tabular}

에서 Staphylococcus aureus, Listeria monocytogenes, Bacillus cereus, Enterobacter sakazaki, Escherichia coli 등의 병 원성 미생물은 모두 검출되지 않았다.

원분뇨 및 기타 액비공정에서 동정되지 않은 Vibrio sp. 가 1 차 폭기조에서 동정된 것은 원분뇨 성상 차이에 의한 결 과로 추측되며, 액비화 과정상에서 폭기에 의해 미생물활성 이 증가하고 이때 발생한 열에 의해 사멸된 것으로 보인다. 실제로 Beaudet (1990)에 의하면 돼지 분뇨의 호기성 분해 는 대부분의 병원성 미생물, 바이러스, 기생충 등의 사멸효 과가 있음이 확인된 바 있다.

\section{연속적인 4 차례의 폭기 이후 미생물 군집의 분포 변} 화에 따른 액비 성상변화 비교 액비화 공정 초기단계에 서 고속 폭기를 통한 미생물 군집의 분포 변화와 성상분석 결과에서 급격한 변화를 보인 것과 상이하게 $\mathrm{BOD}_{5}$ 의 값은 액비 저장조까지 평균적으로 $1500 \mathrm{mg} \mathrm{L}^{-1}$ 로 일정하게 유지 되었다. 그러나 $\mathrm{COD}_{\mathrm{Mn}}$ 의 경우 4 차 폭기조를 거친 후 액비 저장조까지 약 $90 \%$ 감소됨을 확인할 수 있었다. 일반적으 로 대부분의 폐수에서 $\mathrm{COD}_{\mathrm{Mn}}$ 값은 물속에 들어있는 아질산
염, 유기물, 제 1 철 염 등을 산화시켜 사용된 산화제의 양을 나타내는 값으로 미생물에 의해 분해 가능한 유기물의 산소 소모량을 나타내는 $\mathrm{BOD}$ 값보다 크게 나타난다.

그러나 본 연구에서는 4 차 폭기조를 거친 이후 $\mathrm{COD}_{\mathrm{Mn}}$ 값 이 급격하게 감소하는 것과 달리 $\mathrm{BOD}_{5}$ 값은 상대적으로 일 정하였는데, 이것은 폭기 과정에서 분석된 Nitrosomonadales 속의 미생물 및 Nitrobacter vulgais 미생물에 의한 질산화 로 비롯되었을 것으로 사료된다. 실제로 액비 시료 내 총 질 소의 농도는 감소하는 경향을 보였으나 그 정도는 고속 폭 기단계에 비해 낮음을 알 수 있었고, $\mathrm{T}-\mathrm{N}$ 의 농도와 $\mathrm{NH}_{3}$ 형 태의 질소 농도 차이가 증가함을 고려하였을 때, $\mathrm{NH}_{3}$ 형태 의 질소는 대부분 $\mathrm{NH}_{3}-\mathrm{N}, \mathrm{NO}_{3}-\mathrm{N}$ 의 형태로 전환되었을 것 으로 추측된다. 이러한 결과는 $\mathrm{BOD}_{5}$ 수치에 비해 낮은 $\mathrm{COD}_{\mathrm{Mn}}$ 농도가 분석된 원인으로 사료된다.

\section{2차 침전조 및 최종 액비 저장조에서의 미생물 군집} 분포 양상 확인 2 차 침전조 시료와 침전조를 거친 후 1 일 6시간 $40 \sim 50 \mathrm{Km} \mathrm{h}^{-1}$ 의 포기 방식의 액비 저장조에서 시 료를 채취하고 미생물 군집의 분포양상을 확인하였다. 분석결 과 폭기 후 2차 침전조 시료에서는 Firmicutes, Bacteroidetes 문이 증가되는 양상을 확인할 수 있었으며, 특히 Firmicutes 문의 경우 액비 저장조에서 전체 미생물 문의 절반 이상인 약 $53.65 \%$ 비율로 우점하고 있음을 확인하였다. 반면에 Proteobacteria, Actinobacteria 문의 경우 폭기과정 이후 감소하는 경향을 나타내었다.

2차 침전조, 액비 저장조 두 곳에서 농촌진흥청 고시 제 2012-34호에 따라 가축분뇨 발효 액에서 불검출 되어야 하 는 Escherichia coli, Salmonella sp. 등의 병원성 미생물은 검출되지 않았다. 이외 추가적인 5 개 종의 병원성 미생물을 분석한 결과 Staphylococcus aureus, Listeria monocytogenes, Bacillus cereus, Enterobacter sakazaki, Vibrio sp. 등은 검출되지 않았다.

\section{2차 침전조 및 최종 액비 저장조에서의 액비 성상} 확인 전체적인 액비화 공정 및 액비 저장조에서 유해물 질에 대한 분석을 실시하였다. 액비내 함유할 수 있는 최대 유해성분의 최대량이 비소 $0.5 \mathrm{mg} \mathrm{kg}$, 카드뮴 $0.5 \mathrm{mg}$ $\mathrm{kg}^{-1}$, 수은 $0.2 \mathrm{mg} \mathrm{kg}^{-1}$, 납 $15 \mathrm{mg} \mathrm{kg}$, 크롬 $30 \mathrm{mg} \mathrm{kg}^{-1}$, 구리 $50 \mathrm{mg} \mathrm{kg}$, 아연 $130 \mathrm{mg} \mathrm{kg}$, 니켈 $5 \mathrm{mg} \mathrm{kg}^{-1}$ 임을 고려하였을 때, 분석을 실시하지 않은 수은과 크롬을 제외 한 모든 분석항목에서 기준치 이하의 농도로 분석되었다 (Fig. 5).

고속폭기 이후 돈분내 미생물 군집의 heat map 분 석 및 계통수 확인 각 액비화 공정에서 $1 \%$ 이상의 양적 비율로 존재하는 미생물의 비교를 위하여 강 (class) 수준에 


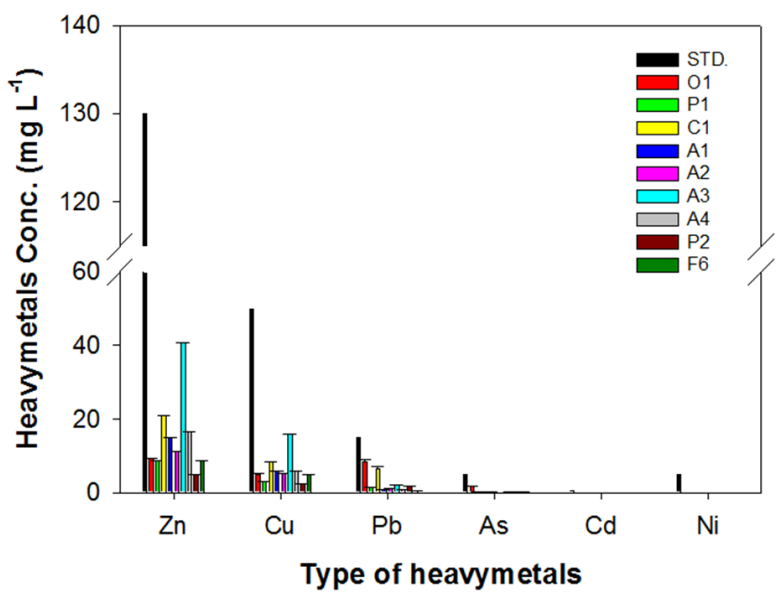

Fig. 5. Heavy metals concentration analysis of nine different fertilization process.

서 Heat map분석을 실시하였다 (Fig. 6). 그래프에서 붉은 색에 가까울수록 공정내 미생물 군집의 개체수가 상대적으 로 낮음을 의미하며, 초록색에 가까울수록 처리공정의 미생 물 개체수가 상대적으로 높음을 의미한다. 분석결과 개별적 인 공정 내에서 $3 \%$ 이상의 군집 수를 보인 강 수준의 미생 물은 Clostridia, Bacteroidia를 포함한 12 개 강이었다.

MEGA 5.1 (USA)를 이용하여 NGS 분석을 통해 얻은 미 생물 군집의 data를 바탕으로 계통학적 분류를 실시하였으 며, 결과를 Fig. 7에 나타내었다. 각 공정에서 분석된 미생 물 군집을 바탕으로 계통도 분석을 실시한 결과 원분뇨로부 터 각 액비화 단계에 따른 계통학적인 개연성을 확인 할 수 있었다.

\section{고속폭기 이후 돈분내 미생물 군집의 OTUs 분석}

Kim et al. (2013)에 따라 Mothur을 이용하여 전체 미생물 군집의 rerafraction과 OTUs의 수를 분석하였다. Song et al. (2012)에 따르면 NGS 분석에서 생성된 read 간의 진화 적 거리와 유사도를 근거로하여 액비화 공정시료의 총 미생 물 군집의 OTUs (Operational Taxanomic Units), 시료내의 미생물 개체수에 대한 정보를 얻을 수 있으며, 이러한 결과 들은 시료내 미생물의 다양성 (Simpson's index), 풍부함 (Chao, abundance-based coverage estimator), 균등성 (Shannon's index) 등의 알파 다양성 수치를 얻을 수 있음을 제시하였다.

본 연구에서는 액비화 공정내 미생물 군집의 richness를 분석하기 위하여 $97 \%$ 유의성 수준에서 rarefaction curve를 계산하였다 (Fig. 8). Rarefaction curve의 $\mathrm{x}$ 축은 무작위로 뽑아낸 read 수를 나타내며, y축은 추출한 read들을 클러스 트링 했을 때의 OTUs의 수를 나타낸다. 다양한 종이 존재 하는 샘플이라면, 무작위로 추출하는 read의 수가 커지면 커질수록 그 안에서 형성되는 클러스터의 수는 계속해서 증 가하는 양상을 보이며, 반대로 종 다양성이 낮은 샘플일 경

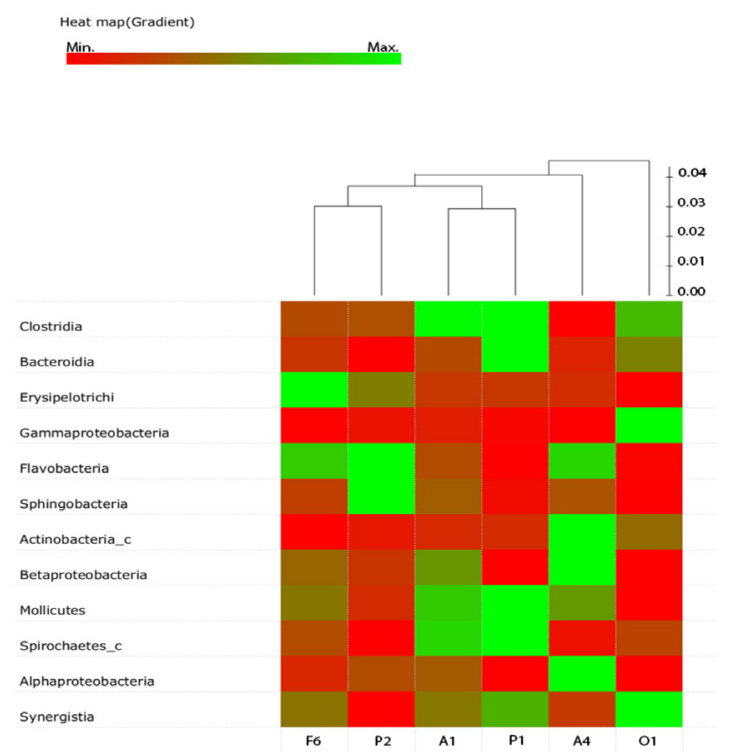

Fig. 6. Heat map analysis of five different process in class level.

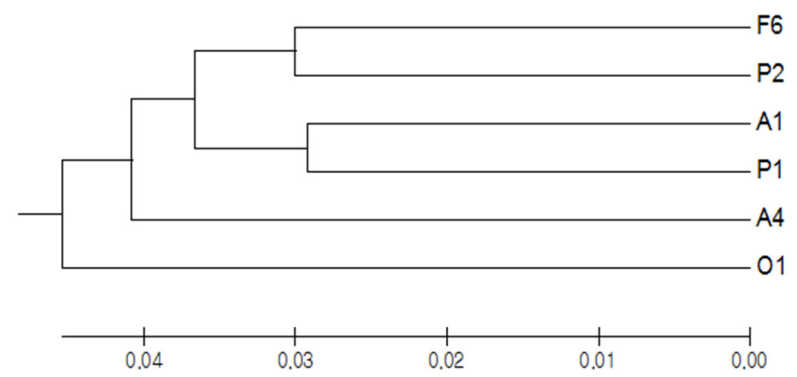

Fig. 7. Relation each process of swine fertilization.

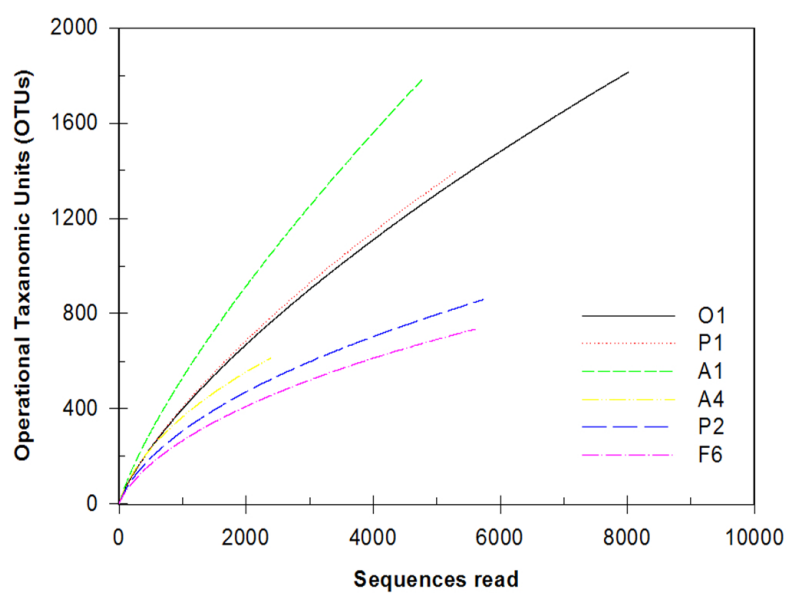

Fig. 8. Rarefaction curve of OTUs analysis in swine waste fertilization process.

우, 무작위로 추출하는 read의 개수가 많아져도 어느 순간 부터 더 이상 OTUs의 수는 증가하지 않게 된다.

분석결과 액비화 과정 동안 미생물의 OTUs는 고속폭기 이후 미생물의 상대적인 수는 증가함을 확인하였다. 1차 침 
전조 시료는 원분뇨와 유사하였으며, 1 차 폭기조에서 가장 높은 미생물군집 다양성을 확인 할 수 있었다. 1 차 폭기부 터 4차 폭기조까지 연속적인 폭기를 거친 이후 최종 액비 저장조까지 군집의 다양성은 감소하는 경향을 보였다. 초기 돈분뇨에서 감소된 미생물의 수는 최종액비 저장조에서 가 장 많았다.

\section{Conclusions}

액비화 과정에서 미생물 군집 변화에 따른 액비의 성상 변화를 확인하기 위하여 경남 지역의 $\mathrm{A}$ 축사에 설비된 액비 화 시설에서 액비화 단계별로 채취한 시료를 대상으로 분석 을 실시하였다. 분석결과 경남 $\mathrm{A}$ 액비자원화 시설 내 액비화 과정의 약 $89.6 \%$ 를 Firmicutes, Bacteroides, Proteobacteria, Actinobacteria 4 개의 문이 작용함을 확인하였으며, 액비화 초기 고속폭기 동안 액비 내 주요 우점 미생물은 주로 내생 포자를 형성하는 Firmicutes 문임을 확인하였다. 그리고 이 러한 미생물들이 액비 성상에 미치는 영향은 다음과 같음을 확인하였다.

1. 액비화 초기 고속폭기 동안 미생물에 의한 유기물에 분 해 및 침전에 의해 $\mathrm{COD}_{\mathrm{Mn}}$ 의 농도는 약 $94.1 \%, \mathrm{BOD}_{5}$ 의 농도는 약 $87.8 \%$ 감소를 확인하였으며, 초기에 상대적 인 분포비율이 높은 Firmicutes 문이 유기물의 감소에 많은 영향을 준 것으로 사료된다.

2. 1 4차까지의 연속적인 폭기 과정상에서 Nitrosomonadales, Nitrobacter vulgais 등의 미생물에 의한 질산 화가 이루어지며, 다음과 같은 공정에서 $\mathrm{BOD}_{5}$ 농도를 분석할 경우 질산화 미생물에 의해 유기물 산화에 필요 한 산소량이 증가하여 상대적으로 $\mathrm{COD}_{\mathrm{Mn}}$ 의 농도에 비 해 높게 나올 수 있음을 확인 하였다.

3. 또한, 식물의 품종에 따라 이용할 수 있는 질소의 형태 가 다름을 고려하였을 때, 완숙된 액비 내의 질소형태 에 영향을 주는 액비화 단계 및 생성된 액비가 작물의 생육에 미치는 영향에 대한 추가적인 연구가 필요하다 고 사료된다.

4. 일반적으로 액비화 과정 참여하는 미생물 군집에 영향 을 줄 수 있는 환경적인 원인으로는 유입되는 돈분뇨 의 성상 및 각 과정상의 온도, $\mathrm{pH}$, 용존산소, 체류시간 등이 있으며, 이러한 환경인자가 미생물의 생장에 미 치는 영향에 대한 추가적인 연구를 통하여 실제적으로 작물 생육에 알맞은 액비의 제조를 기대하는 바이다.

\section{References}

Adams, I.P., R.H. Glover, W.A. Monger, R. Mumford, E.
Jackeviciene, M. Navalinskiene, M. Samuitiene, and N. Boonham. 2009. Next-generation sequencing and metagenomic analysis: a universal diagnostic tool in plant virology. Mol. Plant Pathol. 10:537-545.

Beaudet, R., C. Gagnon, J. Bisaillon, and M. Ishaque. 1990. Microbiological aspects of aerobic thermophilic treatment of swine waste. Appl. Environ. Microbial. 56(4):971-976.

Dong, X. and G.B. Reddy. 2010. Soil bacterial communities in constructed wetlands treated with swine wastewater using PCR-DGGE technique. Bioresour. technol. 101:1175-1182.

Gajewska, E. and M. Sklodowska. 2009. Nickel-induced changes in nitrogen metabolism in wheat shoots. J. Plant Physiol. 166:1034-1044.

Gutierrez, J., C.O. Hong, B.H. Lee, and P.J. Kim. 2010. Effect of steel-making slag as a soil amendment on arsenic uptake by radish (Raphanus sativa L.) in an upland soil. Biol. Fertil. Soils. 46:617-623.

Gangwar, S. and V.P. Singh. 2011. Indole acetic acid differently changes growth and nitrogen metabolism in Pisum sativum $\mathrm{L}$. seedlings under chromium (VI) phytotoxicity: Implication of oxidative stress. Sci. Hortic. 129:321-328.

Hess, T.F., I. Grdzelishvili, H. Sheng, and C.J. Hovde. 2004. Heat inactivation of $E$. coli during manure composting. Compost sci. Utilization. 12: 314-322.

Hölzel, C., K. Harms, H. Küchenhoff, A. Kunz, C. Müller, K. Meyer, K. Schwaiger, and J. Bauer. 2010. Phenotypic and genotypic bacterial antimicrobial resistance in liquid pig manure is variously associated with contents of tetracyclines and sulfonamides. Appl. Microbiol. 108:1642-1656.

Jin, S.N., H.J. Lee, and S.D. Oh. 2003. Growth, leaf nitrogen contents, and nitrate reductase activity in pear (Pyrus pyrifolia cv. Niitaka) trees as affected by ammonium and nitrate nitrogen supply. J. Kor. Soc. Hort. Sci. 44(1):82-86.

Jung, K.S., S.G. Heu, E.J. Roh, D.H. Lee, J.C. Yun, and K.H. Kim. 2011. Prevalence of pathogenic bacteria in livestock manure compost and organic fertilizer. Korean J. Soil Sci. Fert. 44(5):824-829.

Jeong, K.H., M.A. Khan, C.H. Kim, D.H. Lee, D.Y. Choi, and Y.H. Yu. 2012. Effect of aeration mechanism on livestock manure liquid fertilization. J. Organic Agri. 20(4):703-713.

Kim, D.I. and D.H. Kim, 2006, Bacterial community structure and diversity of the Zoysia japonica soil treated with liquid fertilizer containing amino acids. Korean J. Microbiol. 42(2):103-110.

Kim, K.S. 2007. The present conditions and measures for ocean dumping of livestock extra wastes in korea. J. Of The Korean Society Of Marine Environmental \& Safety. 13(4):27-35.

Kim, T.S., H.S. Kim, S.D. Kwon, and H.D. Park, 2010. Analysis of bacterial community composition in wastewater treatment bioreactors using 16S rRNA gene-based pyrosequencing. Korean J. Microbiol. 46(4):352-358.

Kwon, Y.R., J. Kim, B.K. Ahn, S.B. Lee, 2010. Effect of Liquid 
Pig Manure and Synthetic Fertilizer on Rice Growth, Yield, and Quality. Korea J. of Environmental Agriculture. 29(1): 54-60.

Kim, B.C., S. Kim, T. Shin, H. Kim, and B.I. Sang. 2013. Comparison of the Bacterial Communities in Anaerobic, Anoxic, and Oxic Chambers of a Pilot A2O Process Using Pyrosequencing Analysis. Curr. Microbiol. 66(6):555-565.

Nam, Y.D., S.Y. Lee, and S.I. Lim. 2012. Microbial community analysis of Korean soybean pastes by next-generation sequencing. Int. J. Food Microbiol. 155(1-2):36-42.

Park, H.S., J.H. Sul, and M.H. Chiang, 1998. Effects of ammonium and nitrate on callus growth of tobacco and soybean and activities of nitrogen metabolizing enzymes. Korean J. Plant Tissue Culture. 25(1):57-61.

Park, E.J., J. Chun, C.J. Cha, W.S. Park, C.O. Jeon, and J.W. Bae. 2011. Bacterial community analysis during fermentation of ten representative kinds of kimchi with barcoded pyrosequencing. Food microbiol. 30(1):197-204.

Reysenbach A.L., L.J. Giver, G.S., Wickham and N.R., Pace. 1992. Differential amplification of rRNA genes by polymerase chain reaction. Appl Environ Microbiol. 58(10):3417-3418.
Ryoo, J.W., 2010. Effects of mixture application of concentrated pig slurry and byproduct liquid fertilizer on the growth and yield of chinese cabbage. Korean J. of Organic Agriculture. 18(2):271-282.

Sung, G.M., D.G. Lee, and S.J. Park. 2011. The bacterial community structure in biofilms of the RABC process for swine butchery wastewater treatment. Korean J. Microbiol. 47(1):56-65.

Song, J.Y., B.K. Kim, S.K. Kwon, M.J. Kwak, and J.F. Kim. 2012. Next-generation sequencing for environmental biologyfull-fledged environmental genomics around the corner. Korean J. Environ. Biol. 30(2):77-89.

Unno, T., J. Jang, D. Han, J.H. Kim, M.J. Sadowsky, O.S. Kim, J. Chun, and H.G. Hur. 2010. Use of barcoded pyrosequencing and shared OTUs to determine sources of fecal bacteria in watersheds. Environ. Sci. Technol. 44:7777-7782.

Wagner M., A. Loy, R. Nogueira, U. Purkhold, N. Lee, H. Daims. 2002. Microbial community composition and function in wastewater treatment plants. Antonie Leeuwenhoek Int. J. Gen. M. 81:665-680. 